[Volume-II Issue-II][Pages = VI-XV] [Feb 2020]

Website: http://usajournalshub.com/index.php/tajssei ISSN (e): 2689-100X

Impact Factor 2019 (5.366) Impact Factor For Current Year (5.525)

\title{
Principles Of Criminal Procedure In The System Of Guaranteeing The Rights Of Participants In Criminal Court Proceedings
}

\section{Article Doi:- https://doi.org/10.37547/tajssei/Volume02Issue02-01}

\author{
Dildora Bazarova, \\ Phd In Law, Acting Professor \\ At The Department Of Criminal Procedure Of Law \\ And Criminalistics Of The Tashkent State University Of Law, Uzbekistan
}

\begin{abstract}
In this article the author analyses the criminal procedure principles which have a significant impact on the level of ensuring the guarantee of the rights and freedoms of participants in criminal court proceedings, suggests their systematization and improving the possibility of their direct application, especially in the pre-trial proceedings of criminal cases.
\end{abstract}

Keywords: criminal procedure principles, judicial control, legality

Introduction

It is well known that the effectiveness of the criminal justice policy of any state is, first of all, determined by the level of compliance of the existing criminal court proceedings with modern requirements of the sphere. These requirements imply a perfected criminal procedure legislation based on international criminal justice standards and the organic implementation of the fundamental provisions of the legislation of democratic states in this area aimed at provision of comprehensive and reliable guarantee of human rights and freedoms, irrespective of procedural status of the participant of a criminal case.

During the phased reforms of the national criminal justice system in Uzbekistan, the main subject is the reform of pre-trial proceedings of criminal cases, which acts as the bearer of the most characteristic features of the national criminal justice system and is influenced by the political regime of the state, the impact of moral, ethical, national historical, social and economic factors prevailing in the system of relations between the state, society and the individual. 
[Volume-II Issue-II][Pages = VI-XV] [Feb 2020]

Website: $\underline{\text { http://usajournalshub.com/index.php/tajssei }}$ ISSN (e): 2689-100X

Impact Factor 2019 (5.366)

Impact Factor For Current Year (5.525)

The above-mentioned ideas are confirmed by the opinion of international observers who propose a number of drastic measures to reform pre-trial proceedings in Uzbekistan, up to excluding the stages of pre-trial verification and initiating a criminal case, which should be replaced (compensated) by "independent judicial control" in order to simplify pre-trial proceedings which, they believe, "remains cumbersome, ineffective, and characterized by red tape and weak provision of guarantees of human rights."

This position regarding the criminal justice reforms taking place in our country is based on the arbitration method of legal regulation known in theory, which is also called the "judicial" or "judicial proceedings', which envisages criminal court proceedings only in an adversarial process and is carried out only by the court.

At the same time, justice and judicial control are the main forms of exercising the function of judiciary. Justice - a form inherent in the judicial stages of criminal proceedings, and judicial control - in preliminary (pre-trial) stages ${ }^{2}$. In other words, “... Judicial control activities at the preliminary investigation and justice are two separate areas of judicial work, although they sometimes provide for the fulfilment of the unified functions of the judiciary. ${ }^{3 \prime \prime}$

Before considering the impact of the principles of criminal court proceedings on guarantees of the rights and freedoms of its participants, we think it would be appropriate to address certain theoretical problems regarding the procedural functions of criminal court proceedings, criminal procedural principles and bases. Hence, they ultimately determine the types of criminal court proceedings as an organization of criminal procedural activities provided by the method of distribution of the three main procedural functions which identify movement of criminal court proceedings and the basis of the procedural status of its participants, guarantees of their rights and freedoms.

\section{Argumentation}

To date, among legal scholars there is no single understanding of the criminal procedure functions and their significance for the organization of a truly adversarial process in which the parties (the prosecution and the defence) should be endowed with equal procedural opportunities and the court real independence. The most acceptable, in our opinion, is the position of A.I. Makarkin, who, on the basis of a thorough study of points of the scholars in this sphere of the past and modern time, comes to a conclusion "... that the separation of the main criminal procedural functions is the way of organizing criminal procedural activity, in which the main source of movement of the case is the dispute of parties with equal rights before an independent court. ${ }^{4 \prime \prime}$

Developing his position, this author rightly asserts "that the separation of criminal procedural functions is one of the abstract elements of adversarial process, since it is connected not only with the concept of the development of freedom of an autonomous individual, but also with the idea of separation of powers in the state, and with the laws of division of labour, and laws of psychology ", in connection with which it is possible to determine a specific type of criminal court proceedings as an organization of the criminal procedure. 
[Volume-II Issue-II][Pages = VI-XV] [Feb 2020]

Website: $\underline{\text { http://usajournalshub.com/index.php/tajssei }}$ ISSN (e): 2689-100X

Impact Factor 2019 (5.366)

Impact Factor For Current Year (5.525)

It is well known that the regulatory framework of guarantees ensuring the rights and freedoms of participants of criminal court proceedings is provided by constitutional provisions and principles of criminal procedure. In the legal literature, regarding the principles of the criminal procedure, their concepts, structure (hierarchy), content, role and significance for the protection of the rights and freedoms of participants of criminal court proceedings in criminal cases, various points of view are also expressed $^{6}$.by scholars in this sphere. The most attractive to us is the classification of the principles of criminal court proceedings proposed by S.D. Shestakova, which, depending on the nature of the connection with the form of the process are divided into:

1) the principles that determine (constitute) the form of the process;

2) guarantee principles, ensuring the implementation of the principles that determine the form of the process;

3) principles indifferent to the form of the process and giving it a concrete historical image.

It should be noted that the author of the above classification of principles discloses their system in relation to the adversarial type of criminal court proceedings, the formation of which, by the way, is one of the most important areas of criminal justice reform in Uzbekistan.

To the first group of principles that determine the form of the process, the author relates the administration of justice only by the court; criminal prosecution only by the prosecution; providing the accused with the right to defence and equal rights of the parties.

Among the guarantee principles that ensure the implementation of the principles that determine the form of the process, she distinguishes: the independence of judges and their subjection only to the law; assessment of evidence based on inner conviction; personal integrity; inviolability, privacy of private life, privacy of correspondence, telephone conversations, telegraphic and other communications; presumption of innocence; orality, publicity of court proceedings, immediacy of the investigation of the circumstances of the case.

To the category of principles that are indifferent to the form of the process and that give it an appropriate concrete historical image, the above-mentioned author refers such principles as a combination of unity of undivided authority and collegiality, the exercise of justice on the basis of equality of citizens before the court, and others ${ }^{7}$.

We may share the opinion of those legal scholars in the criminal procedure law who consider that the principles of criminal procedure are manifestations of the type (model) of criminal court proceedings, by which it is necessary to understand the organization of criminal procedure, which determines the source of movement of the proceedings in the criminal case and the basis of the procedural status of its participants ${ }^{8}$.

In the theory of criminal procedure law, it is customary to consider the presence of two main types - adversarial type and, opposed to it, the investigative type, based on completely opposite principles, which in the scientific literature are often called ideal due to the polarity and abstractness of their content ${ }^{9}$. 
[Volume-II Issue-II][Pages = VI-XV] [Feb 2020]

Website: http://usajournalshub.com/index.php/tajssei ISSN (e): 2689-100X

Impact Factor 2019 (5.366)

Impact Factor For Current Year (5.525)

It is because of the extreme abstractness of their content that in reality there are no ideal types of court proceedings, and real types are mixed. At the same time, both adversarial and investigative ideal types of criminal court proceedings are subdivided into specific types, which in theory are distinguished into certain varieties containing certain characteristics and features, all of which also affect the state and level of guaranteeing the rights and freedoms of participants of criminal court proceedings.

So, theoretically the adversarial type of court proceedings is divided into: indictment, lawsuits (private lawsuit and public lawsuit) and public-adversarial court proceedings, which can be briefly described as follows:

a) in the indictment procedure, the main goal of both parties, i.e. the prosecutor and the accused is achieving a victory in a dispute, which is fixed by a decision of the judicial authority. Moreover, the observance by the parties of the formal conditions of the dispute, when the evidence is evaluated by the court according to pre-established criteria (formal system of evidence), is of paramount importance. Bail, oath, the judicial standoff are widely used as a means of resolving a dispute in this type of adversarial court proceedings;

b) the private lawsuit procedure is carried out exclusively depending on the will of the parties (private plaintiff and defendant), each of which, even a representative of state authority participating in the process, acts as a private person, which ensures the formal equality of the parties. The burden of proof rests entirely with the parties, and the court evaluates the evidence they have presented based on inner conviction. The use of elements of formal evidence is also allowed;

c) the public lawsuit adversarial system presupposes the participation of a special state criminal prosecution body that defends public interests. Moreover, the equality of the parties is ensured by providing the accused with a certain set of passive guarantees. The court, when making a decision, is guided by the principle of a free assessment of evidence;

d) the public-adversarial (or post-adversarial, discursive-adversarial) criminal procedure, unlike the previous types, is aimed not at winning the dispute, but at its settlement, localization of the conflict. Parties are not provided with formal, but functional equality. The principles of objective truth and the free assessment of evidence are given serious importance in making judicial decisions.

According to a number of legal scholars whose ideas we share, the last form contains the main features of the most optimal model of the criminal procedure for the modern presentation of the future adversarial court proceedings. Moreover, the term "public-adversarial" is very successful, as it clearly reflects the desire to maintain a balance of private and public interests, which is a characteristic of civil society ${ }^{10}$.

The criminal court proceedings of the investigative type in the theory of criminal procedure law can also be classified by the degree of observance of public interests, that is, by the ratio of public and private interests. So, naturally, all investigative types of the process and some varieties of the adversarial type, such as public-lawsuit and public-adversarial, belong to public, and "non-public" - the indictment and private-lawsuit. The public nature of the process is consistent with the social interest, that is, with 


\section{[Volume-II Issue-II][Pages = VI-XV] [Feb 2020]}

\section{Website: http://usajournalshub.com/index.php/tajssei ISSN (e): 2689-100X}

the interest of the social community recognized by the state and secured by law, the satisfaction of which is a condition and content of its existence and development ${ }^{11}$.

We believe that in the framework of the criminal justice reforms being carried out in our country, the publicity of the adversarial process will play a different role than in the public-law investigative types of court proceedings, where publicity was the primacy of state interest. In our opinion, now and in the long term, the goal of publicity should be to protect such primary values of civil society as an individual, his rights and freedoms.

As previously noted, in reality, there are no ideal types of court proceedings, and the existing and currently existing real types are mixed.

In this regard, in the typology system of criminal court proceedings in science, morphological (historical and legislative) types are distinguished as the real embodiment of those or other principles of ideal types of process, in various proportions ${ }^{12}$. The morphological typology, in contrast to the ideal one, is based on the construction of real types of court proceedings, based on the most common features of court proceedings for various countries and regions resulting from specific historical processes.

In the criminal procedure theory, it is customary to distinguish four morphological types - English, French, German and Sharia (Muslim), which are a manifestation of specific forms of the process that have historically developed in certain countries and served as models for other states and regions, that is, they have become basic models for specific (legislative) forms, named also as national. Accordingly, the British morphological type includes the criminal procedure in Great Britain, the USA, Australia, while the French historical form, includes apart from France, the criminal procedural systems of Belgium, Italy, Russia, as well as a number of post-Soviet countries. The German type is constituted by judicial systems of Germany, Austria, Norway, Hungary. The Muslim historical form of court proceedings based on Sharia law includes the criminal procedure in Iran, Afghanistan, the United Arab Emirates and other countries ${ }^{13}$.

It should be noted that the modernization of criminal procedural activities in Uzbekistan, which involves the introduction and development in court proceedings of forms, principles and individual legal norms that meet international standards in guaranteeing human rights and interests, to some extent echoes the similar activities in the Russian Federation, where legal scholars also conduct various scientific, theoretical and practical research in this area, whose views are of interest to the researchers of Uzbekistan.

So, according to A.I. Makarkin, who has a number of interesting studies on improving the criminal procedure and is a supporter of the development of adversarial principles at various stages of criminal proceedings, "the attitude to adversarial type among scholars in this sphere is extremely ambiguous, opinions are expressed both in its support and against. Among the legal practitioners surveyed there is also no unity. $69 \%$ of judges, $88 \%$ of lawyers, $50 \%$ of investigators of the Ministry of Internal Affairs and only $15 \%$ of prosecutors spoke in favour of converting the form of the Russian criminal procedure into adversarial.

Moreover, even those scholars, who saw a global trend in the development of criminal court proceedings in expanding the principles of adversarial type, did not develop a clear answer to the 
[Volume-II Issue-II][Pages = VI-XV] [Feb 2020]

Website: $\underline{\text { http://usajournalshub.com/index.php/tajssei }}$ ISSN (e): 2689-100X

Impact Factor 2019 (5.366)

Impact Factor For Current Year (5.525)

question of how to determine the place of the legislative form of the process at a particular historical moment in the adversarial-investigative system. It seems insufficient to confine to recognition of each morphological type as mixed, since this does not give the possibility of a systematic definition even in the short term, which in itself could be of great importance, primarily of a theoretical nature."

Based on the fact that all real types of criminal court proceedings are mixed and include features of both ideal types, the specific gravity of which is manifested in specific national forms of the criminal procedure depending on the period of the historical development of a particular state and combines a different volume of basic features of ideal types, is in a dynamic state and development. Thus, it can be assumed that the national (legislative) type of court proceedings of any state can be characterized depending on the proportion of the features of ideal types. The aforementioned A.I. Makarkin, who believes that "to describe such a process, contrary to popular belief, based on an ideal typology, is not only possible, but necessary" and "attempts have also been made in the literature", but also "they were often unsystematic and resembled labelling ${ }^{14 \prime \prime}$.

The above-mentioned author also proposes to classify legislative forms of criminal court proceedings depending on development trends with respect to the investigative or adversarial ideal type, dividing them into pre-adversarial and post-adversarial, pre-investigative and post-investigative, the difference between which is very arbitrary, but allows you to take into account "not only the direction in which legislation moves, but also the clear predominance of certain elements ${ }^{15}$." By "elements" the author most likely understands principles of adversarial and investigative ideal types of criminal procedure.

In our opinion, the definition of the national type of criminal court proceedings in Uzbekistan at the present stage should be the subject of a separate scientific study, which will have not only theoretical, but also practical value to confirm and justify the need, timeliness and expected effectiveness of measures currently being taken in Uzbekistan to improvement of criminal court proceedings capable of effectively solving the tasks of combatting crime and providing guarantees for the observance of rights, freedoms and the legitimate interests of citizens participating in criminal court proceedings.

As can be seen from the above theoretical conclusions and assumptions regarding the interconnections between the national form of criminal court proceedings and the current organizational and functional principles of the court proceedings, on the basis of which specific procedural rules are formed that determine the level of guarantees of the participants in the process, criminal procedure principles are given an important, most likely key provision of general rules, which are the basis of all criminal procedure activities and subordinating all other rules, detailed in the norms of criminal procedure legislation.

The principles of the criminal procedure listed in Chapter 2 of the current Code of Criminal Procedure of the Republic of Uzbekistan, in general, reflect individual democratic principles in national criminal court proceedings contained in a number of international documents, namely the Universal Declaration of Human Rights, the Declaration of Basic Principles of Justice for Victims of Crime and Abuse 
[Volume-II Issue-II][Pages = VI-XV] [Feb 2020]

Website: http://usajournalshub.com/index.php/tajssei ISSN (e): 2689-100X

Impact Factor 2019 (5.366)

Impact Factor For Current Year (5.525)

of Power, in the European Convention for the Protection of Human Rights and Fundamental Freedoms, in the International Covenant on Civil and Political Rights, in the Basic principles of the independence of the judiciary, in the United Nations Standard Minimum Rules for Non-custodial Measures (Tokyo Rules) and other international legal acts. ${ }^{16}$

Despite the fact that the constitutional principles, which were further developed and regulated in criminal procedure legislation as the principles of criminal court proceedings and, at first glance, demonstrate the capabilities of the national legal system to protect the rights and freedoms of participants in the process, it should be noted that formulated in a declarative form not provided with a well-thought-out implementation mechanism, the principles are not always effective and are not essential for practical support of guarantee of the rights of participants in the process, protect their legitimate interests.

Having regard to the statement of A.S. Aleksandrova, who believes that in a mixed process some principles (principles of one ideal form) dominate, while others are in a "minimized" state ${ }^{17}$, we consider it possible to conduct targeted scientific and theoretical research aimed at determining the real relationship in the current national criminal procedure principles and bases of adversarial and investigative ideal types to ascertain legislative type of our criminal court proceedings.

At the same time, this study will make it possible to develop scientifically based recommendations and assumptions on the systematization of criminal procedural principles, on the formation and inclusion in the system of principles of additional fundamental principles, on making changes to the content of principles, their presentation, taking into account modern procedural terminology, advanced international standards, logical sequence and clarity of regulation, which excludes the possibility of different interpretations and applications.

In the national Code of Criminal Procedure, legality is the first among the principles of the criminal procedure, which is quite traditional for the legal systems of most countries. Despite a certain decrease in the number of publications in the legal literature devoted to the problems of legality, research issues of legality remain relevant today, especially for our state, in which radical changes are taking place in criminal court proceedings. At the same time, it is necessary to take into account the situation that when considering this category as a phenomenon with a complex internal structure, researchers demonstrate the multilateralism of approaches to the legality, its concept, content and meaning, without questioning the indisputability of the fact that this general legal principle of legality in the field of criminal court proceedings is based on strict, accurate, consistent observance and enforcement of the criminal procedure law by all participants of public relations.

In addition, in a number of definitions, legality is revealed through the category "regime", i.e. legality is seen as a stable social (or legal) regime, characterized by universal, strict implementation of legal norms.

Legality is also defined as a method of implementing the tasks of the state, i.e. a means of ensuring the protection of public and private interests. Thus, the content of the concept of "legality" is significantly expanded, since it includes the processes of law-making and the realisation of law. A review 
[Volume-II Issue-II][Pages = VI-XV] [Feb 2020]

\section{Website: http://usajournalshub.com/index.php/tajssei ISSN (e): 2689-100X}

Impact Factor 2019 (5.366)

Impact Factor For Current Year (5.525)

of the above definitions of legality indicates that they all reflect the real-life features and properties of this complex and multifaceted social phenomenon.

Thus, all four ("compliance and realisation", "principle", "regime", "method") of the above-stated version of the concept of legality define it as the properties of legal activity (including the law-making and realisation processes) by all participants of public relations.

In recent years, attempts have been made to significantly expand the content of legality by including legislation in this concept ("legality" is associated with compliance with not only laws, but also by-laws that are based on them: government decrees, orders, instructions, regulations, recommendations), reducing at the expense of its subjective composition (usually citizens are excluded from the list of subjects of legality), i.e. citizens are required to comply only with laws, and with legality officials and government authorities (deputies, police officers, prosecutors, judges).

From the point of view of guaranteeing the rights and freedoms of citizens in criminal court proceedings, the manifestation of the legality is, first and foremost, the exact and strict observance of the criminal procedure law precisely from the bodies and officials involved in the criminal court proceedings, that is, from the court (judges or the composition of the court), prosecutors, investigators (of prosecution office, internal affairs, state security service), employees of inquiry bodies, who, due to the fulfilment of tasks and the process functions are endowed with power to influence the behaviour of subjects of criminal procedure relations. It should be noted that the mechanism of legal influence on the behaviour of subjects in the field of criminal court proceedings as an integrated system of special (exceptional) means that ensures the normal functioning of the institutions of society which includes strict regulatory methods, often associated with an intervention in constitutional rights and freedoms of citizens. Coercion is a natural attribute of criminal procedure law, although it certainly does not exhaust other methods of influencing the behaviour of participants in the process. The modern theory of law, distinguishing between the concepts of legal influence and legal regulation, rightly states that legal regulation is not identical to coercion, it is a strict and powerful prescription. The latter is more characteristic of law enforcement norms and relations, but by this, of course, legal regulation is not exhausted ${ }^{18}$.

At the same time, it is known that the above-listed officials responsible for organizing the process and obliged to protect and ensure the protection of the rights of participants in the process do not always fulfil the requirement to comply with the criminal procedure and often themselves initiate violations. According to some scholars, "the arbitrariness of the law enforcer is a consequence of the lack of specification of the requirement elevated to a principle. ${ }^{19}$ " At the same time, they are proposing, when formulating the principle of legality in criminal court proceedings, to more clearly state the provisions aimed at ensuring its real action, including the inadmissibility of violation of the law, mandatory liability of an official, invalidation of illegal acts and their cancellation, and other procedural and legal consequences for officials. It is also recommended in a similar way to formulate a number of other principles: the administration of justice only by the court; judicial protection of human rights and 
[Volume-II Issue-II][Pages = VI-XV] [Feb 2020]

\title{
Website: http://usajournalshub.com/index.php/tajssei ISSN (e): 2689-100X
}

\author{
Impact Factor 2019 (5.366) Impact Factor For Current Year (5.525)
}

freedoms; respect for the honour and dignity of the individual; personal integrity; protection of the rights and freedoms of citizens and others.

\section{Conclusion}

Given the reform of national court proceedings in the direction of making significant changes and additions to the pre-trial stages of the criminal procedure, in which violations of the rights and freedoms of participants are often observed, we consider it appropriate, within the framework of certain topics, to investigate the possibility of strengthening the principles of the criminal procedure during the preinvestigation, initiation (refusal) of a criminal case, inquiry and preliminary investigation, preparation of the materials of the criminal case and submission to the court, as well as the application of measures procedural coercion, including preventive measures. In addition, these studies should be aimed at a comprehensive study of the main objective and subjective reasons, factors contributing to violations of the principles of the criminal procedure by officials responsible for organizing criminal court proceedings in pre-trial stages.

Summarizing the above, the following conclusions and assumptions can be made: the criminal procedure principles have a significant impact on the level of ensuring the guarantee of the rights and freedoms of participants in criminal court proceedings; the list of principles regulated in the national criminal procedure legislation requires a certain systematization and additions; the content of many principles of the criminal procedure requires a more extensive exposition and concretization in order to reduce the degree of their declarativeness and enhance the possibility of their direct application, especially in the pre-trial stages of criminal court proceedings.

\section{References:}

${ }^{1}$ Proposals for the concept of improving the system of criminal and criminal procedure legislation of the Republic of Uzbekistan. UNODC, www.unodc.org

${ }^{2}$ Makarkin A.I. Adversarial process at the preliminary investigation / Editor: Doctor of Law, prof. V.V.

Vandyshev. - St. Petersburg: Publishing House "Legal Center Press", 2004. - p.37.

${ }^{3}$ Kolokolov N.A. Judicial control at the stage of preliminary investigation of crimes: an important function of the judiciary: Abstract of dissertation candidate of legal science. M., 1998. p. 13

${ }^{4}$ Ibid, p.26

${ }^{5}$ Ibid, p.26

${ }^{6}$ Dobrovolskaya T.N. The principles of the Soviet criminal process. M., 1971, p. 79; Strogovich M.S. Criminal process. M., 1946.S. 73; Criminal Procedure Law of the Russian Federation / Editor: P.A. Lupinskaya. M., 1999.p. 150-153; Kuzub I.R. The criminal procedural function of protecting the rights and legitimate interests of the perpetrators of the crime: Abstract of dissertation candidate of legal science. Izhevsk, 2000. S.7-17; Ogneva I.A. Human rights activist in criminal proceedings in Russia: Abstract of 
[Volume-II Issue-II][Pages = VI-XV] [Feb 2020]

Website: http://usajournalshub.com/index.php/tajssei ISSN (e): 2689-100X

Impact Factor 2019 (5.366) Impact Factor For Current Year (5.525)

dissertation candidate of legal science. M., 2000. S. 9.17-18; Filimonov B.A. Defender in the German criminal process. M., 1997.S. 20; and etc.

${ }^{7}$ Shestakova S.D. Adversarial process problems in the Russian criminal trial: Diss. Candidate of Law. SPb., 1998. P. 55-56.

${ }^{8}$ Vandyshev V.V., Derbenev A.P., Smirnov A.V. Criminal process: educational-methodical manual. Part 1. St. Petersburg, 1996.p. 15-23; Makarkin A.I. Op. Cit. p.14; others

${ }^{9}$ Cheltsov-Bebutov M.A. Criminal Procedure Law Course. St. Petersburg, 1995.,p.589-590; Faynitsky I.Ya. The course of criminal court proceedings: In 2t. SPb., 1996 .T.1. p. 59-61; Smirnov A.V. Models of the criminal process. SPb., 2000, p. 18-19;

${ }^{10}$ Smirnov A.V. 1) Models of the criminal process. St. Petersburg, 2000, p. 26-58; 2) Adversarial process. St. Petersburg, 2001, p. 27-55, 221-311. Makarkin A.I. Decree. Op. p.16-17.

${ }^{11}$ Tikhomirov Yu.A. Public law. M., 1995. p. 54.

${ }^{12}$ Smirnov A.V. Models of the criminal process. SPb. 2000, p.15-17.

${ }^{13}$ Smirnov A.V. Adversarial process. SPb., p.134-220.

${ }^{14}$ Ibid, p. 19-21

${ }^{15}$ Ibid

${ }^{16}$ See: International Human Rights Acts: Collection of documents. M., 2000; International Covenants on Human Rights: Collection of documents. SPb., 1993.

${ }^{17}$ Alexandrov A.S. Dispositivity in criminal proceedings: Abstract of dissertation candidate of legal science. N. Novgorod. 1995, p. 7, 16.

${ }^{18}$ General theory of state and law. Academic course in 2 volumes / Ed. prof. M.N. Marchenko. T.2. - M.: Publishing. "Mirror", 1998, - S. 437.

${ }^{19}$ Volodina L.M. The problems of guarantees in the criminal process \Bulletin of OSU No. 3 / March 2006. p.42-43. 